\title{
EFEKTIVITAS MODEL PEMBELAJARAN KOOPERATIF TIPE THINK PAIR SHARE (TPS) TERHADAP KEMAMPUAN KOMUNIKASI MATEMATIS SISWA KELAS VII SMP
}

\section{THE EFFECTIVENESS OF COOPERATIVE LEARNING MODEL TYPE THINK PAIR SHARE (TPS) TOWARDS STUDENTS MATHEMATICAL COMMUNICATION ABILITY GRADE VII SMP}

\author{
Ayu Lestari'1), Nur Kholisah Latuconsina ${ }^{2}$, Andi Ulmi Asnita ${ }^{3)}$ \\ 1,2,3)Fakulats Tarbiyah dan Keguruan Universitas Islam Negeri Makassar \\ ayu.lestaribmc.07@gmail.com ${ }^{11}$, nurkhalisaltc99@gmail.com ${ }^{2)}$, ulmi.asnita@uin-alauddin.ac.id ${ }^{3}$ )
}

\begin{abstract}
Abstrak
Penelitian ini bertujuan untuk mengetahui apakah model pembelajaran Kooperatif tipe Think Pair Share (TPS) efektif dalam meningkatkan kemampuan komunikasi matematis peserta didik kelas VII SMPN 2 Patalassang Kabupaten Gowa. Penelitian ini merupakan penelitian eksperimen dengan jenis penelitian quasi experimental design dengan nonequivalent control group design. Populasi dalam penelitian ini terbagi ke dalam 4 kelas kemudian dengan penentuan sampel menggunakan simple random sampling. Instrumen yang digunakan berupa tes kemampuan komunikasi matematis terbagi atas pretest dan posttest. Teknik analisis yang digunakan adalah statistik deskriptif dan statistik inferensial. Hasil analisis deskriptif menunjukkan bahwa rata-rata kemampuan komunikasi matematis siswa dengan model pembelajaran kooperatif tipe TPS adalah 78,2926 berada pada kategori tinggi dengan persentase $66,667 \%$ dan rata-rata kemampuan komunikasi matematis siswa tanpa model pembelajaran kooperatif tipe TPS adalah 74,1944 pada kategori tinggi dengan persentase 88,111\%. Hasil analisis inferensial menunjukkan bahwa terdapat perbedaan yang signifikan antara kemampuan komunikasi matematis siswa antara kelas yang diajar dengan model pembelajaran kooperatif tipe TPS dengan kelas tanpa model pembelajaran kooperatif tipe TPS. Selanjutnya, hasil uji lanjut menunjukkan bahwa pembelajaran dengan model pembelajaran kooperatif tipe TPS lebih efektif meningkatkan kemampuan komunikasi matematis siswa dibandingkan dengan tanpa model pembelajaran kooperatif tipe TPS.
\end{abstract}

Kata Kunci: komunikasi matematis, model pembelajaran kooperatif tipe TPS.

\begin{abstract}
This research investigates the effectiveness of Think Pair Share (TPS) cooperative learning model in enhancing seventh grade student's mathematical communication at SMP Negeri 2 Patalassang in Gowa Regency. It employs quasi experimental research design with non-equivalent control group design to investigate the issue. The population of this research is divided into 4 classes and decided with simple random sampling technique. The instruments used in this research consist of pre-test and post-test of mathematical communication ability. The data were analysed using descriptive and inferential statistic. The research findings suggest that the results of the descriptive analysis show a high level of student's mathematical communication ability when taught with the TPS model, indicated by an average score of 78.2926 with a percentage of $66.667 \%$. However, the findings also signify an equally high level of student's mathematical communication ability without being taught with TPS model, indicated by an average score of 74.1944 with a percentage of $88.111 \%$. The results of the inferential analysis, meanwhile, show that there is a significant difference of student's mathematical communication ability between the classes who were taught with the
\end{abstract}


TPS model and those who were not, signified. Furthermore, an advanced testing shows that the TPS learning model is more effective in enhancing student's mathematical communication ability than the learning without the implementation of the TPS model.

Keywords: mathematical communication, TPS cooperative learning model

How to Cite: Lestari, A., Latuconsina, N.K., \& Asnita, A.U. (2019). Efektivitas model pembelajaran kooperatif tipe Think Pair Share (TPS) terhadap kemampuan komunikasi matematis siswa kelas VII SMP. Al-Asma: Journal of Islamic Education, 1(2), 125-135.

\section{PENDAHULUAN}

Pendidikan merupakan suatu hal yang sangat penting bagi semua individu dan hampir semua individu atau personal pernah merasakan pendidikan dari dulu sampai saat ini. Pendidikan merupakan proses pembudayaan kodrat alam setiap individu dengan kemampuan-kemampuan bawaan untuk dapat mempertahankan hidup, yang bertuju pada pencapaian kemerdekaan lahir dan batin sehingga memperoleh keselamatan lahir dan batin, serta memperoleh keselamatan dalam hidup lahiriah dan batiniah (Triwiyanto, 2017: 62).

Pendidikan merupakan usaha sadar untuk menumbuh kembangkan potensipotensi peserta didik melalui kegiatan pembelajaran. Siswa dituntut untuk bersikap aktif, kreatif, inovatif dan memiliki kemampuan berpikir logis dalam merespon setiap pelajaran yang akan diajarkan. Untuk menumbuhkan sikap aktif, kreatif maupun inovatif pada peserta didik bukanlah suatu hal mudah, diperlukan langkah-langkah yang telah direncanakan secara matang agar tujuan dalam pendidikan tersebut tercapai.

Matematika merupakan satu di antara bidang studi yang memiliki peranan penting dalam pendidikan. Dalam mempelajari matematika seorang dituntut untuk memiliki kemampuan logis, analitis, sistematis, kritis, dan kreatif serta kemampuan bekerjasama. Oleh karena itu, matematika diajarkan pada semua jenjang pendidikan mulai dari sekolah dasar sampai keperguruan tinggi (Mallo dkk, 2016: 455). Matematika merupakan salah satu mata pelajaran yang menekankan arti penting dari komunikasi. Hal ini tertuang dalam Standar National Council of Teacher of Mathematics (NCTM) 2000 dimana kemampuan komunikasi menjadi salah satu standar proses dalam pembelajaran matematika. Komunikasi matematika merupakan proses esensial pembelajaran matematika karena melalui komunikasi, siswa merenungkan, memperjelas dan memperluas ide dan pemahaman mereka tentang hubungan dan argument matematika (Palinno, N.S \& Ikman , 2015:92). Kemampuan komunikasi matematis sangat penting bagi siswa karena mereka dapat memecahkan masalah matematika dengan menggunakan penalaran yang baik, mengilustrasikan ide matematika ke dalam model matematika, dan kemudian menghubungkan proses ke berbagai konsep matematika ke dalam konteks kehidupan sehari-hari (Tinungki, 2015: 27).

Berdasarkan hasil wawancara dengan salah satu guru mata pelajaran Matematika kelas VII saat melakukan observasi yang dilaksanakan oleh peneliti pada hari Kamis, 29 Maret 2018 khususnya pada mata pelajaran matematika kelas VII SMP Negeri 2 Patalassang Kabupaten Gowa, beliau menuturkan bahwa "siswa lebih cenderung mengikuti instruksi guru tanpa adanya umpan balik, kurang percaya diri dalam mengemukakan jawabannya atau pendapat karena takut salah, jarang ada siswa yang 
mau maju untuk menjawab soal di depan kelas ini di sebabkan rendahnya kemampuan komunikasi matematis siswa dalam menyajikan pernyataan dan menjawab soal-soal matematika secara lisan maupun tulisan.

Salah satu yang dapat mengembangkan kemampuan komunikasi matematis peserta didik adalah model pembelajaran kooperatif dimana pembelajaran yang berpusat pada siswa. Pembelajaran kooperatif adalah kegiatan pembelajaran dengan cara berkelompok untuk bekerjasama saling membantu mengkontruksi konsep dan menyelesaikan persoalan (Shoimin, 2016:45). Pembelajaran kooperatif dalam matematika dapat membantu peserta didik dalam meningkatkan rasa percaya dirinya. Peserta didik secara individu dapat percaya diri terhadap kemampuan yang dimiliki dalam menyelesaikan masalah-masalah maatematika, sehingga mengurangi rasa takut yang dialami.

Model pembelajaran kooperatif tipe Think Pair Share (TPS) adalah salah satu tipe pembelajaran kooperatif yang merangsang aktivitas siswa secara berpasangan dan berbagi pengetahuan kepada siswa lainnya (Lestari, 2015:83). Model ini merupakan cara yang sederhana pertama-tama, guru mengajukan satu pertanyaan /masalah kepada mereka. Setiap siswa diminta untuk berpikir sendiri-sendiri terlebih dahulu tentang jawaban atas pertanyaan itu, kemudian siswa diminta untuk duduk barpasangan untuk mendiskusikan hasil pemikirannya dengan pasangan disebelahnya untuk memperoleh suatu persetujuan yang sekiranya dapat mewakili jawaban mereka berdua. Setelah itu, guru meminta setiap pasangan untuk, menjelaskan atau menjabarkan hasil persetujuan atau jawaban yang telah mereka sepakati pada siswa-siswa yang lain di ruang kelas (Huda, 2011:132). Hal ini akan meningkatkan kemampuan komunikasi matematis siswa. Dalam proses pembelajaran matematika menggunakan model pembelajaran kooperatif tipe Think Pair Share (TPS) siswa dipandu oleh guru untuk meningkatkan pengetahuan matemaika dirinya sendiri secara bertahap.

Hal tersebut diperkuat dengan berbagai hasil penelitian sebelumnya diataranya yaitu penelitian yang dilakukan oleh Novita Silvany Palino dan Ikman pada 1 Januari 2015 melakukan penelitian terkait dengan model pembelajaran Tipe Think Pair Share (TPS) dengan judul " Pengaruh Penerapan Pembelajaran Kooperatif tipe Think Pair Share terhadap Kemampuan Komunikassi Matematik Siswa Kelas VIII SMP Negeri 5 Kendari”. Hasil peneliatian yang telah dilakukan yaitu peningkatan kemampuan komunikasi matematik siswa yang diajar dengan menggunakan pembelajaran kooperatif tipe Think Pair Share (TPS) lebih baik secara signifikan dari pada peningkatan kemampuan komunikasi matematik siswa yang diajar dengan menggunakan pembelajaran konvensional. Ini juga membuktikan bahwa penerapan pembelajaran kooperatif tipe TPS memiliki pengaruh yang signifikan terhadap kemampuan komunikasi matematik siswa (Palinno, N.S \& Ikman , 2015:105). Hasil penelitian lainnya dari Rhohmat Atik Nurul Khasanah, dkk dengan judul "Keefektifan Model Pembelajaran Think Pair Share dengan Pendekatan Kontekstual terhadap Kemampuan Komunikasi Matematis Pada Materi Statistika Kelas VII". Hasil peneliatian yang yang telah dilakukan yaitu model pembelajaran Think Pair Share dengan pendekatan Kontekstual efektif terhadap kemampuan komunikasi matematis peserta didik daripada model pembelajaran ekspositori (Khasanah dkk, 2016: 305). 
Pembelajaran kooperatif merupakan aktivitas pembelajaran kelompok yang diorganisir oleh satu prinsip bahwa pembelajaran harus didasarkan pada perubahan informasi secara sosial di antara kelompok-kelompok pembelajaran yang di dalamnya setiap pembelajaran bertanggung jawab atas pembelajarannya sendiri dan didorong untuk meningkatkan pembelajaran anggota-anggota yang lain (Huda, 2011: 29). Pembelajaran kooperatif adalah suatu model pembelajaran dimana siswa belajar dan bekerjasama secara kolaboratif dalam suatu kelompok kecil yang terdiri atas 4-5 orang siiswa dengan struktur kelompok heterogen. Pembelajaran ini bertujuan untuk mengembangkan prestasi akademik, keterampilan sosial, dan menanamkan toleransi dan penerimaan terhadap keanekaragaman individu (Lestari, 2015: 43).

Pembelajaran kooperatif menyumbangkan ide kepada siswa yang bekerja sama dalam belajar dan bertanggung jawab terhadap teman satu timnya mampu membuat diri mereka belajar sama baiknya. Sebagai tambahan terhadap gagasan tentang kerja kooperatif, metode Student Team Learning (Pembelajaran Tim Siswa ) mekankan penggunaan tim dan sukses tim, yang akan dapat di capai apabila semua tim bisa belajar mengenia pokok bahasan yang telah diajarkan ( Slavin, 2005: 10)

Pembelajaran kooperatif tipe Think Pair Share disingkat dengan TPS merupakan pembelajaran yang memfokuskan pada kemampuan siswa. TPS memberikan kesempatan kepada siswa untuk bekerja sendri sekaligus bekerjasama dengan teman yang lain, sehinnga siswa dapat mencari solusi untuk memecahkan masalah yang diberikan untuk kemudian dapat mengembangkan pemahamannya yang telah didapat(Palinno, N.S \& Ikman , 2015:93).

Menurut Kumandar, Think Pair Share merupakan jenis pembelajaran koperatif yang dirancang untuk mempengaruhi pola interaksi siswa. TPS merupakan salah satu model pembelajaran yang dikembangkan dari teori kontruktivisme yang merupakan perpaduan antara belajar secara mandiri dan belajar secara berkelompok. Model pembelajaran kooperatif tipe TPS mampu mengubah asumsi bahwa metode resitasi dan diskusi perlu diselenggarakan dalam setiap kelompok kelas seacara keseluruhan. Tipe ini memberikan kepada para siswa waktu untuk berpikir dan merespon serta saling bantu satu sama lain (Nini dkk, 2015:157).

Menurut Trianto, pembelajaran kooperatif tipe TPS dapat melatih dan mengembangkan kemampuan berpikir serta aktivitas siswa, karena siswa membangun pengetahuan melewati eksplorasi dirinya sendiri dan pengetahuan siswa juga bisa berkermbang melalui transfer pola pikir dengan siswa yang lain, sehingga siswa mampu memgabungkan dan membandingkan pola pikir mereka sendiri dengan pola pikir siswa untuk berpikir dan merespon satu sama lain. Menurut Nurnawati mengatakan bahwa TPS juga juga dapat meningkatkan partisipasi siswa, cocok untuk tugas sederhana, lebih mudah dalam pembentukan kelompok, dan dapat digunakan untuk semua mata pelajaran serta semua tingkatan anak usia didik( Nurulia, 2016: 45). Menurut Adellucky, model kooperatif tipe Think Pair Share (TPS) memiliki prosedur yang ditetapkan secara eksplisit untuk memberi siswa waktu lebih banyak untuk berpikir, menjawab dan saling membantu satu sama lain, guru menginginkan siswa memikirkan secara mendalam tentang apa yang telah dijelaskan atau dialami (Nini dkk, 2015: 157). 
Berdasarkan uraian di atas maka pembelajaran kooperatif tipe Think Pair Share merupakan suatu pembelajaran memberikan waktu kepada peserta didik untuk berinteraksi, berpikir dan merespon serta saling bantu dengan peserta didik yang lain. Dengan model pembelajaran kooperatif tipe Think Pair Share (TPS) dapat meningkatkan atau mengembangkan kemampuan berpikir dan aktivitas peserta didik, karena adanya transfer pola pikir atau pendapat dengan peserta didik yang lain. Sehinnga dapat menghubungkan, membandingkan pola pikir mereka dan memdapatkan suatu persetujuan.

Sintaks model kooperatif tipe Think Pair Share (TPS) yaitu: (Huda, 2011:136-137) (a) Siswa ditempatkan dalam kelompok-kelompok. Setiap kelompok terdiri dari empat anggota/siswa, (b) Guru memberikan tugas pada setiap kelomok, (c) Masing-masing anggota memikirkan masalah tersebut sendiri-sendiri terlebih dahulu, (d) Kelompok membetuk angota-anggotanya secara berpasangan. Setiap pasangan mendiskusikan hasil pemikiran setiap individu, (e) Kedua pasangan lalu bertermu kembali dalam kolompoknya masing-masing untuk membangi hasil diskusinya.

Adapun kelebihan Model Pembelajaran Kooperatif tipe Think Pair Share (TPS) yaitu (Shoimin, 2016: 211-212) (a) TPS Mudah diterapkan diberbagai jenjang pendidikan dan dalam setiap kesempatan, (b) Menyediakan waktu berpikir untuk meningkatkan kualitas respons siswa, (c) Siswa lebih menjadi lebih aktif dalam berpikir mengenai konsep dalam mata pelajaran, (d) Siswa lebih memahami tentang konsep topik pelajaran selama diskusi, (e) Siswa dapat belajar dari siswa lain. Sedangkan kekurangan dari Model Pembelajaran Kooperatif tipe Think Pair Share (TPS) sebagai berikut: (Shoimin, 2016: 212) (a) Banyak kelompok yang melapor dan perlu dimonitor, (b) Lebih sedikit ide yang muncul, (c) Jika ada perselisihan tidak ada penengah. Kemampuan komunikasi matematis adalah kemampuan untuk menyampaikan gagasan/ide matematis, baik secara lisan maupun tulisan serta kemampuan memahami dan menerima gagasan/ide matematis orang lain secara cermat, analitis, kritis, dan evaluative untuk mempertajam pemahaman.(Lestari, 2005: 82). Menurut Son, menyatakan bahwa komunikasi matematis adalah proses mengekspresikan ide-ide dan pemahaman matematika secara lisan, visual, tertulis, menggunakan angka, simbol, gambar, grafik, diagram, dan kata-kata. Jadi, kemampuan komonikasi matematis merupakan kemampuan yang harus dimiliki oleh peserta didik guna dapat menayatakan ide-idenya ke dalam matematika dengan baik.(Khasanah, 2016: 300). Menurut Dina, adanya simbol-simbol maka tampak jelas bahwa peserta didik harus mempunyai kemampuan komunikasi matematis untuk dapat mengkomunikasikan gagasan dengan tabel, diagram dan grafik. Kemampuan komunikasi matematis merupakan kemampuan peserta didik menggunakan matematika sebagai alat komunikasi dan kemampuan peserta didik mengkomunikasikan matematika yang dipelajari sebagai isi pesan yang harus disampaikan (Khasanah, dkk 2016:299).

Berdasarkan uraian diatas maka kemampuan komunikasi matematis yaitu proses menyampaikan gagasan atau ide-ide dan pemahaman matematika secara lisan ataupun tulisan dengan menngunakan angka, simbol, gambar, grafik, maupun diagram. Dengan adanya kemampuan komunikasi matematis peserta didik dapat menggunakanya sebagai alat komunikasi untuk mengomunikasikan matemetika yang dipelajari sebagai isi pesan yang disampaikan. 
Indikator-indikator kemampuan komunikasi matematis yaitu: (a) Menghubungkan benda nyata, gambar, dan diagram ke dalam ide matematika, (b) Menjelaskan ide, situasi, dan relasi matematika secara lisan atau tulisan, dengan benda nyata, gambar, grafik dan aljabar, (b) Menyatakan peristiwa sehari-hari dalam bahasa matematika, (c) Mendengarkan, diskusi, dan menulis tentang matematika, (d) Membaca dengan pemahaman suatu persentasi mateatia tertulis, (e) Menyusun pertanyaan matematika yang relevan dengan situasi masalah, (f) Membuat konjektur, menyusun argument, merumuskan definisi dan generalisassi. (Lestari, 2005:83).

\section{METODE PENELITIAN}

Pendekatan yang dilakukan dalam penelitian ini adalah pendekatan kuantitatif dengan jenis penelitian eksperimen semu dengan desain penelitian The Non-Equivalent Control Group. Penelitian ini dilakukan di SMP Negeri 2 Patalassang Kabupaten Gowa, Provinsi Sulawesi Selatan. Populasi dalam penelitian ini adalah seluruh siswa kelas VII SMP Negeri 2 Patalassang Kabupaten Gowa sejumlah 144 siswa. Sampel dalam penelitian ini adalah siswa kelas VII.1 terdiri dari 36 siswa sebagai kelas eksperimen dan siswa kelas VII.2 terdiri dari 36 siswa sebagai kelas kontrol di SMP Negeri 2 Patalassang Kabupaten Gowa.

Tes kemampuan komunikasi matematis siswa kelas VII.1 dan VII.2 adalah tes sebelum perlakuan (pretest) dan tes setelaah perlakuan (posttest). Bentuk tes yang diberikan adalah tes tertulis dengan jenis tes uraian. Teknik analisis data yang digunakan dalam penelitian ini adalah statistik deskriptif dan statistik inferensial. Uji prasyarat dalam penelitian ini adalah uji normalitas, uji homogenitas kemudian pengujian hipotesis dilanjutkan dengan uji efektivitas.

\section{HASIL DAN PEMBAHASAN}

Berdasarkan pretest dan posttest yang diberikan pada peserta didik di kelas eksperimen menggunakan model kooperatif tipe Think Pair Share (TPS) pada saat proses pembelajaran di kelas VII.1 sebagai berikut:

Tabel 1. Rekapitulasi Kemampuan Komunikasi Matematis pada Kelas Eksperimen

\begin{tabular}{lcc}
\hline \multirow{2}{*}{ Statistik } & \multicolumn{2}{c}{ Nilai Statistik Kelas VII.1 } \\
\cline { 2 - 3 } & Pretest Kelas Eksperimen & Posttest Kelas Eksperimen \\
\hline Jumlah Sampel & 36 & 36 \\
Nilai Terendah & 23 & 67 \\
Nilai Tertinggi & 63 & 88 \\
\hline
\end{tabular}

Berdasarkan tabel di atas, maka dapat diketahui bahwa skor maksimum yang diperoleh pretest dengan menggunkan model kooperatif tipe Think Pair Share (TPS) pada kelas eksperimen 63, sedangkan nilai minimum adalah 23. Skor maksimum yang diperoleh posttest dengan menggunkan model kooperatif tipe Think Pair Share (TPS) pada kelas eksperimen 88, sedangkan nilai minimum adalah 67. 
Tabel 2. Distribusi Frekuensi dan Persentase Kemampuan Komunikasi Matematis Pretest dan Posttest Kelas Eksperimen

\begin{tabular}{|c|c|c|c|c|c|}
\hline \multirow[b]{2}{*}{ Interval } & \multirow[b]{2}{*}{ Kategori } & \multicolumn{2}{|c|}{ Pretest Kelas Eksperimen } & \multicolumn{2}{|c|}{ Posttest Kelas Eksperimen } \\
\hline & & Frekuensi & Persentase(\%) & Frekuensi & Persentase(\%) \\
\hline $0-20$ & $\begin{array}{l}\text { Sangat } \\
\text { Rendah }\end{array}$ & 0 & 0 & 0 & 0 \\
\hline $21-40$ & Rendah & 17 & 47,222 & 0 & 0 \\
\hline $41-60$ & Sedang & 16 & 44,445 & 0 & 0 \\
\hline $61-80$ & Tinggi & 3 & 8,333 & 24 & 66,667 \\
\hline $81-100$ & $\begin{array}{c}\text { Sangat } \\
\text { Tinggi }\end{array}$ & 0 & 0 & 12 & 33,333 \\
\hline JUI & LAH & 36 & 100 & 36 & 00 \\
\hline
\end{tabular}

Berdasarkan tabel diatas, maka dapat dilihat bahwa kemampuan komunikasi metematis peserta didik pada kelas eksperimen pada saat pretest yaitu tidak ada peserta didik $(0 \%)$ pada kategori sangat rendah, 17 peserta diidk pada kategori rendah $(47,222 \%), 16$ peserta diidk pada kategori sedang (44,445\%), 3 peserta didik pada kategori tinggi $(8,333 \%)$ dan tidak ada peserta didik $(0 \%)$ pada kategori sangat tinggi. Sedangkan kemampuan komunikasi metematis peserta didik pada kelas eksperimen pada saat posttest yaitu tidak ada peserta didik (0\%) pada kategori sangat rendah, tidak ada peserta diidk pada kategori rendah (0\%), tidak ada peserta diidk pada kategori sedang (0\%), 17 peserta didik pada kategori tinggi $(54,8387 \%)$ dan 14 peserta didik $(45,1613 \%)$ pada kategori sangat tinggi. Jadi dapat disimpulkan bahwa persentasi terbesar pada kelas eksperimen pada saat pretest berada pada kategori rendah sedangkan persentasi terbesar pada kelas eksperimen pada saat posttest berada pada kategori tinggi.

Gambaran kemampuan komunikasi matematis peserta didik pada kelas eksperimen yang diajar menggunakan model pembelajaran kooperatif tipe Think Pair Share (TPS), nilai rata-rata yang diperoleh peserta didik sebelumnya 41,75 menjadi 78,29 hal tersebut menunjukkan bahwa peserta didik mengalami peningkatan yang disebabkan oleh pemahaman materi yang diterima pada saat proses pembelajaran yang melekat dalam diri peserta didik sehingga kemampuan komunikasi matematisnya dapat ditingkatkan secara optimal. Standar deviasi yang diperoleh sebelumnya 12,035 menjadi 5,228 hal tersebut menunjukkan bahwa ukuran penyebaran data pada saat pretest lebih bervariasi dibandingkan pada saat posttest. Kemampuan komunikasi matematis peserta didik mengalami peningkatan yang sebelumnya berada pada kategori rendah naik ke kategori tinggi.

Berdasarkan pretest dan posttest yang diberikan pada peserta didik di kelas kontrol tanpa menggunakan model kooperatif tipe Think Pair Share (TPS) pada saat proses pembelajaran di kelas VII.2 sebagai berikut: 
Tabel 3. Rekapitulasi Kemampuan Komunikasi Matematis pada Kelas Kontrol

\begin{tabular}{lcc}
\hline Statistik & \multicolumn{2}{c}{ Nilai Statistik Kelas VII.1 } \\
\cline { 2 - 3 } & Pretest Kelas Kontrol & Posttest Kelas Kontrol \\
\hline Jumlah Sampel & 36 & 36 \\
Nilai Terendah & 23 & 63 \\
Nilai Tertinggi & 60 & 82 \\
\hline
\end{tabular}

Berdasarkan tabel di atas, maka dapat diketahui bahwa skor maksimum yang diperoleh pretest tanpa menggunkan model kooperatif tipe Think Pair Share (TPS) pada kelas kontrol 60, sedangkan nilai minimum adalah 23. Skor maksimum yang diperoleh posttest dengan tanpa model kooperatif tipe Think Pair Share (TPS) pada kelas kontrol 82, sedangkan nilai minimum adalah 63.

Tabel 4. Distribusi Frekuensi dan Persentase Kemampuan Komunikasi Matematis Pretest dan Posttest Kelas Kontrol

\begin{tabular}{|c|c|c|c|c|c|}
\hline \multirow[t]{2}{*}{ Interval } & \multirow[t]{2}{*}{ Kategori } & \multicolumn{2}{|c|}{ Pretest Kelas Eksperimen } & \multicolumn{2}{|c|}{ Posttest Kelas Eksperimen } \\
\hline & & Frekuensi & Persentase(\%) & Frekuensi & Persentase(\%) \\
\hline $0-20$ & $\begin{array}{l}\text { Sangat } \\
\text { Rendah }\end{array}$ & 0 & 0 & 0 & 0 \\
\hline $21-40$ & Rendah & 20 & 55,556 & 0 & 0 \\
\hline $41-60$ & Sedang & 16 & 44,444 & 0 & 0 \\
\hline $61-80$ & Tinggi & 0 & 0 & 31 & 86,111 \\
\hline $81-100$ & $\begin{array}{c}\text { Sangat } \\
\text { Tinggi }\end{array}$ & 0 & 0 & 5 & 13,889 \\
\hline JUI & LAH & 36 & 100 & 36 & 100 \\
\hline
\end{tabular}

Berdasarkan tabel di atas, maka dapat dilihat bahwa kemampuan komunikasi metematis peserta didik pada kelas kontrol pada saat posttest yaitu tidak ada peserta didik (0\%) pada kategori sangat rendah, 20 peserta diidk pada kategori rendah (55,556\%), 16 peserta diidk pada kategori sedang $(44,444 \%)$, peserta didik pada kategori tinggi $(0 \%)$ dan tidak ada peserta didik (0\%) pada kategori sangat tinggi. Sedangkan kemampuan komunikasi metematis peserta didik pada kelas kontrol pada saat pretest yaitu tidak ada peserta didik $(0 \%)$ pada kategori sangat rendah, tidak ada peserta diidk pada kategori rendah $(0 \%)$, tidak ada peserta diidk pada kategori sedang (0\%), 31 peserta didik pada kategori tinggi $(86,11 \%)$ dan 5 peserta didik $(13,889 \%)$ pada kategori sangat tinggi. Jadi dapat disimpulkan bahwa persentasi terbesar pada kelas kontrol pada saat pretest berada pada kategori rendah sedangkan persentasi terbesar pada kelas kontrol pada saat posttest berada pada kategori tinggi.

Gambaran kemampuan komunikasi matematis peserta didik pada kelas kontrol tanpa menerapkan model pembelajaran kooperatif tipe Think Pair Share (TPS), nilai ratarata yang diperoleh peserta didik yang sebelumnya 39,416 menjadi 74,194 hasil ini menunjukkan bahwa adanya peningkatan kemampuan komunikasi matematis pada kelas kontrol meskipun cenderung peserta didik kurang aktif diandingakan dengan kelas 
eksperimen dalam proses pembelajaran. Standar deviasi yang diperoleh sebelumnya 10,3658 menjadi 5,262 hal tersebut menunjukkan bahwa ukuran penyebaran data pada saat pretest lebih bervariasi dibandingkan pada saat posttest. Kemampuan komunikasi matematis peserta didik mengalami peningkatan yang sebelumnya berada pada kategori rendah naik ke kategori tinggi.

Hasil pengujian normalitas pretest dan posttest kelas eksperimen dan kelas kontrol menunjukkan bahwa keseluruhan data berdistribusi normal. Uji homogenias menunjukkan bahwa data homogen. Uji hipotesis menunjukkan bahwa $t_{\text {hitung }}=2,8911$ dan $t_{\text {tabel }}$ dengan $\alpha=0,05$ dan $d k=36+36-2=70$ adalah 1,66 . Karena $t_{\text {hitung }}>$ $t_{\text {tabel }}(2,8911>1,66)$ maka dapat disimpulkan bahwa $\mathrm{H}_{0}$ ditolak, ini berarti bahwa terdapat perbedaan rata-rata antara kelas yang diajar menggunakan model pembelajaran kooperatif tipe TPS dan kelas yang diajar tanpa menggunakan model pembelajaran kooperatif tipe TPS terhadap kemampuan komunikasi matematis peserta diidk di kelas VII SMP Negeri 2 Patalassang Kabupaten Gowa. Uji efisiensi relative (relative efficiency) diperoleh nilai $R<1(0,987<1)$ secara relatif $\hat{\theta}_{1}$ lebih efisien daripada $\hat{\theta}_{2}$. Artinya penerapan pembelajaran dengan menggunkan model pembelajaran koperatif tipe TPS efektif dalam meningkatkan kemampuan komunikasi matematis peserta didik kelas VII SMP Negeri 2 Patalassang Kabupaten Gowa.

Kemampuan komunikasi matematis peserta didik setelah menerapkan model pembelajaran kooperatif tipe TPS berada pada kategori tinggi. Hal tersebut terjadi karena dalam proses belajar mengajar siswa cenderung aktif. Peserta didik dibagi menjadi beberapa kelompok belajar yang terdiri atas empat orang setiap anggota kelompok. Setiap peserta didik memikirkan masalah masing-masing kemudian membentuk pasangan dalam kelompoknya dan mendiskusikan secara bersama dengan pasangannya kemudian kembali berkumpul dengan kelompoknya masing-masing. Proses pembelajaran lebih didominasi oleh peserta didik dari pada guru sehingga pembelajaran lebih menarik dan tidak membosankan. Pada saat diberikan kesempatan untuk mempersentasikan hasil diskusi dengan kelompoknya peserta didik antusias untuk mempersentasikan hasil kelompoknya dan kelompok lain memberikan masukan atau pertanyaan yang kurang dipahami.

Model pembelajaran kooperatif tipe TPS membantu peserta didik untuk mengembangkan kemampuan komunikasi matematisnya, terlebih bagi mereka yang mengalami kesulitan dalam mengomunikasikan ide matematika yang di pahami atau suatu permasalahan matematika yang sulit untuk dimengerti. Dengan adanya pembelajaran kooperatif tipe TPS peserta didik mengeluarkan gagasan yang dimiliki dan disampaikan kepada temannya tanpa ada rasa takut atau canggung. Sehingga menunjang peningkatan kemampuan komunikasi matematis pada peserta didik.

Berdasarkan analisis data hasil kemampuan komunikasi matematis pada kelas kontrol menunjukkan bahwa adanya peningkatan. Namun, peserta didik yang diajar tanpa menggunakan model pembelajaran kooperatif tipe TPS cenderung kurang aktif diandingakan dengan kelas eksperimen dalam proses pembelajaran hal tersebut disebabkan karena peserta didik hanya sebagian yang aktif dalam proses pembelajaran dan peserta didik yang tidak paham dengan materi pembelajaran lebih cenderung bersikap pasif. Apabila diberikan kesempatan untuk bertanya dan menjawab soal didepan kelas hanya sebagian yang bisa. Selain itu, proes pembelajran hanya berpusat kepada guru. Guru menjelaskan materi pembelajaran kemudian dengan ceramah, kemudian 
memberikan tugas kepada peserta didik untuk dikerjakan secara individu. Namun,sejalan dengan pembelajaran tersebut guru menarik perhatian peserta didik untuk aktif dalam proses pembelajaran dengan memberi imbalan kepada peserta didik yang mampu untuk mengerjakan atau menanggapi.

Penelitian ini didukung oleh penelitian terdahulu yang relevan seperti Rhohmat Atik Khasanah yang hasil penelitiannya kemampuan komunikasi peserta didik dengan model pembelajaran TPS dengan pendekatan kontekstual lebih baik dari pada model ekspositori. Sama halnya dengan Novita Silvany Palino yang hasil penelitiannya menyatakan model pembelajaran Think Pair Share dapat meningkatkan kemampuan komunikasi matematis siswa.

Berdasarkan penjelasan di atas dan penelitian terdahulu yang relevan dengan penelitian ini, hal ini berarti mendukung diterimanya hipótesis yaitu model pembelajaran kooperatif tipe Think Pair Share (TPS) efektif dalam meningkatkan hasil belajar matematika siswa kelas VII SMP Negeri 2 Patalassang Kabupaten Gowa.

\section{SIMPULAN}

Berdasarkan hasil penelitian dan pembahasan pada penelitian ini, maka diperoleh kesimpulan kemampuan komunikasi matematis peserta didik yang menggunakan model pembelajaran kooperatif tipe Think Pair Share (TPS) yaitu pada saat pretest adalah $47,222 \%$ pada kategori rendah, 44,445\% pada kategori sedang dan 8,333\% pada kategori tinggi. Sedangkan pada saat posttest adalah $66,667 \%$ pada kategori tinggi dan 33,333\% pada kategori sangat tinggi, kemampuan komunikasi matematis peserta didik tanpa menggunakan model pembelajaran kooperatif tipe Think Pair Share (TPS) yaitu pada saat pretest adalah 55,556\% pada kategori rendah, 44,444\% pada kategori sedang. Sedangkan pada saat posttest adalah $86,111 \%$ pada kategori tinggi dan 13,889\% pada kategori sangat tinggi, berdasarkan analisis diperoleh bahwa $t_{\text {hitung }}>t_{\text {tabel }}(2,8911>1,66)$ maka dapat disimpulkan bahwa $\mathrm{H}_{0}$ ditolak, ini berarti bahwa terdapat perbedaan rata-rata antara kelas yang diajar menggunakan model pembelajaran kooperatif tipe Think Pair Share (TPS) dan kelas yang diajar tanpa menggunakan model pembelajaran kooperatif tipe Think Pair Share (TPS) terhadap kemampuan komunikasi matematis peserta didik, dan berdasarkan analisis diperoleh bahwa $R<1(0,987<1)$ maka pembelajaran dengan menggunkan model kooperatif tipe Think Pair Share (TPS) lebih efektif dalam meningkatkan kemampuan komunikasi matematis peserta didik.

\section{DAFTAR PUSTAKA}

Huda, Miftahul. (2011). Cooperative Learning. Yogyakarta: Pustaka Pelajar.

Khasanah, Rhohmat Atuk Nurul, dkk. (2016) “Kefektivitas Penerapan Model Pembelajaran Think Pair Share Dengan Pendekatan Kontekstual Terhadap Kemampuan Komunikasi Matematis Pada Materi Statistika Kelas VII", Seminar Nasiaonal Pendidikan, Sains dan Teknologi.

Lestari, Karunia Eka dan Mokhammad Ridwan Yudhanegara. (2005). Penelitian Pendidikan Matematika. Jakarta:Grasindo.

Mallo, Nurulia Bakri, dkk. (2015). "Penerapan Model Pembelajaran Kooperatif Tipe Think Pair Share untuk Meningkatkan Hasil Belajar siswa Pada Materi Penjumlahan dan 
Pengurangan Bentuk Aljabar di Kelas VII SMP Negeri 12 Palu", Jurnal Eloktronik Pendidikan Matematika Tadulako 3, no.4.

Nini, Wa Ode, dkk. (2015). "Evektifitas Penerapan Model Pembelajaran Kooperatif Think Pair Share terhadap Hasil Belajar Matematika Materi Pokok Statistika Pada Siswa Kelas IX SMP Negeri 2 Kendari". Jurnal Penelitian Pendidikan Matematika 3 no.4.

Nurulia, dkk. (2016). Penerapan Model Pembelajaran Model Pembelajaran Kooperatif Think Pair Share Untuk Meningkatkan Hasil Belajar Siswa Pada Materi Penjumlahan Dan Pengurangan Bentuk Aljabar Di Kelas VII SMP Negerai 12 Palu. Jurnal Elektronik Pendidikan Matematika Tadulako3 no 4.

Palinno, N.S \& Ikman (2015)“Pengaruh penerapan pembelajaran kooperatif Tipe Think Pair Share Terhadap Kemampuan Komunikasi Matematik Siswa Kelas VIII SMP Negeri 5 Kendari” ,Jurnal Penelitian Pendidikan Matematika 3, no.1.

Shoimin, Aris. (2016). 68 Model Pembelajaran Inovatif dalam Kurikulum 2013. Yogyakarta: Ar-Ruzz Media.

Slavin, Robert E. ( 2005). Cooperative Learning: Theory, Research and Practice (Cooperative Learning Teori, Riset dan Praktik (Terjemahan oleh Narulita Yusron). Bandung: Penerbit Nusa Media.

Tinungki, Maria Georgina. (2015) "The Role Of Cooperative Type Team Assisted Individualization TO Improve the Students' Mathematics Communication Ability in the Subject of Probability Theory", Journal of Education and Practice 6 No. 32.

Triwiyanto, Teguh. (2017). Pengantar Pendidikan. Jakarta: Bumi Aksara. 